\title{
The mining-induced displacement and resettlement: The church as a leaven and ecclesiology in context's response
}

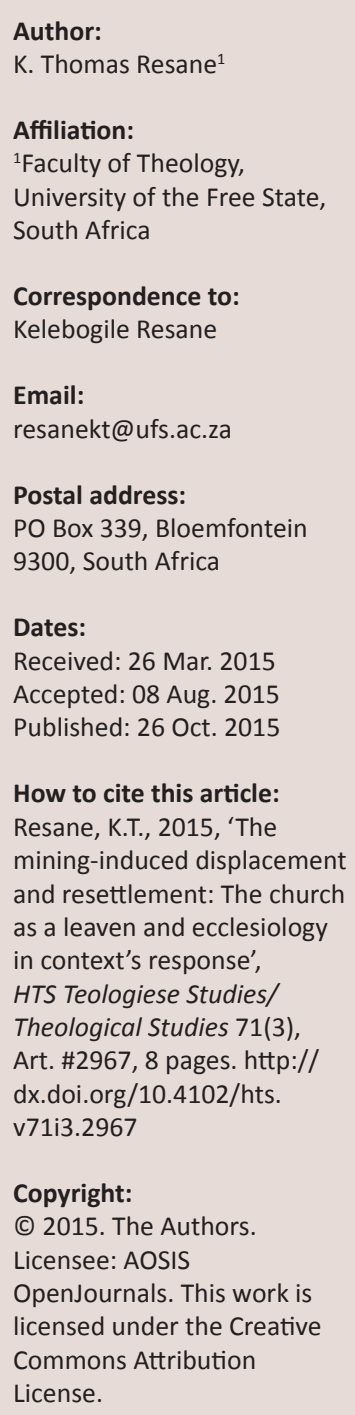

Natural resources, especially minerals from the earth, are to be protected by humanity. The church, which acts as leaven in the world is called to rise and address the unfriendly mining activities called mining-induced displacement and resettlement (MIDR). The general theory of interpretation of creation account calls for human stewardship in the world. Humans must view themselves as partners with God in preserving and sustaining the cosmos. The communities had suffered negative socio-economic imbalances. The ekklesia in this cosmic chaos is called upon to fulfil four major functions, namely identity, integration, policy, and management as a way of intervention in communities that are victims of these mining activities. This response, ecclesiology in context, is the combination of theological and social-scientific approaches to the development of practical models and strategies for the church's interaction with modern society and its challenges.

\section{Introduction}

Natural resources from the earth and environment in general are there for human consumption and livelihood; but in some cases, unfortunately, are for satisfying human greed. Natural resources come to humanity in different classifications via diverse means. These classifications cover a wide range of natural resources such as minerals, water, air, vegetation, and animals. Miller (1992:510) makes an extensive list of these resources. This article examines mining and makes some theological reflections on mining - one way of retrieving the natural resources found in the earth. The discovery of minerals can be viewed as the divine blessing, but also as a bane of human population. The uprooting and relocation of human population together with the environmental impact of mining activities (MIDR) raise some concerns in the research fields of the natural and social sciences.

\section{The natural resources: The genesis account for human responsibility}

The scope of this article focuses on the consequences of the mining activities, and shows that minerals are the natural resources from the earth, but it can have a negative impact on the various populations. A natural resource is not a human invention, as it is already divinely deposited in the earth. Developmental studies state that the universal debates regarding the natural resources revolve around the threatening depletion and exportation driven by first world economies at the expense of producing countries. On a wider scale, the private sector, which is often foreign, amasses the profit, which does not always improve the quality of life for the indigenous populations affected. Natural resources are irreplaceable, therefore it is important for humans to conserve the environment, both for its own sake and also because our livelihoods depend on it (Harris 2005:4).

Mining and mineral extraction is the human endeavour to access the natural resources that are not on the surface of the earth. It is a human economic activity with a very high potential for environmental degradation and pollution. Mining has a strong influence on the social impact and stratification. Foreign companies often have a larger stake, and share it with the national government, marginalising the populations where these activities take place. Consequently, these populations face strenuous socio-economic imbalances.

From time immemorial, Christianity embraced the concept of the imago Dei, found in the Genesis creation account as a pretext for justifying human exploitation of the world's resources. This was specifically enhanced by 'have dominion' and 'subdue' notions of the Genesis account. This approach has always and is still expected to legitimise humans to be the stewards over 
creation. The Christian scientific attitudes of dominion towards ecological responsibility have been very superficial and egocentric. As far back as the eighties, Ronald B. Allen (1984) pointed to a critical place or position of humanity in relation to the cosmos in general. Allen's argument is based on a hermeneutical analysis of Psalm 8 with its irenic tone to instil some deeper appreciation of the richness and goodness of humanity - if properly premised on the fact that stewardship over the creation was the original purpose of God.

The elementary principle of biblical interpretation is that one must not only establish the meaning of words by their etymology alone, but also and especially by the way they are used in context. The closer theological scrutiny of the Genesis account attests to the fact that humans are the stewards of creation, including mineral utilisation. They are partners with God for caring, sustaining, and protecting creation as opposed to lording over it. This is confirmed by one of the evangelical scholars, John Stott (1990), who states that

we have seen that the dominion God has given us is delegated, responsible and co-operative; that it is intended to express the same sustaining care of the environment as its Creator's; and that, far from exploiting the earth and its creatures, we are to use them in such a way as to be accountable to God and to serve others ... The dominion God has given humankind is a conscientious and caring stewardship which involves the husbanding of the earth's resources. It would be ludicrous to suppose that God first created the earth and then handed it over to us to be destroyed. (p. 124)

Humanity is expected to be in partnership with God for the sustainability of creation. This partnership is highlighted by Ted Peters (2004:141), namely that 'theologically speaking, we participate with God in the ongoing creative advance'. The human-creation relationship question had always been there, but the fact of the matter is that stewardship is central to Judaic, Christian and Islamic beliefs. Humanity's role is trusteeship which is accountabe to God concerning the stewardship of the earth. This is the universal call to petition for eco-normative ethics intended to focus Christian ministry on the elements of global ecological change (Stackhouse, Dearborn \& Paeth 2000:115).

Generally the doctrine of creation affirms the importance of human responsibility towards the environment. There are cultural filters that influence human perception of environment. This is attested by Francis Harris (2005:10) when he confirms that the value which individuals, communities and nations place on their environment is affected by cultural and religious values as well as economic and social systems'. Creation is the responsible resource available to humanity for intended positive outcomes. It is entrusted to humans, who are responsible for its safekeeping and tending. In a nutshell, a doctrine of creation can thus act as the basis for an ecologically sensitive ethic (McGrath 2000). The problem is the ecological crisis that Moltmann (1997) emphasises when he says that power and pleasure disturb the equilibrium in the relationships between humanity and nature. Dominance and comfort perpetuated by egoistic ideals disturb this partnership with God for the sustainability of the environment. The mining companies put profit above humans, hence the resultant MIDR.

\section{Overview: Mining and minerals}

Africa produces more than 60 metal and mineral products and is a major producer of several of the world's most important minerals and metals (Miller 1992:176-178). The increase in exploration and mine development primarily focuses on gold and diamond trade. Unfortunately, several African civil wars are funded by (and often caused by) some of these commodities, in particular diamonds. The economic boost of the national budgets comes at the expense of environmental degradation and human population displacements that are accompanied by socio-cultural instabilities.

\section{The constitutional policy: Accessibility and harmless environment}

The international law recognises that States have the right to exercise full and permanent sovereignty over their own natural resources. The principle of public trusteeship of mineral resources is recognised and accepted in all major mining countries such as South Africa. The South African White Paper on Mineral Policy (South Africa, Department of Minerals \& Energy 1998) regarding ownership and management is hereby summarised:

- The State should take a constructive interventionist role in altering the patterns of ownership.

- This Act provides for an official audit of the extent of racial discrimination.

- The mining industry needs to demonstrate rapid, visible and significant transformation in line with the rest of the South African society.

- Mining industries should contribute to insurance and pension funds to secure significant participation in the governance rights of shareholders.

- A broader spread as well as greater participation in managing mining companies on the basis of ownership should be promoted through the development of Employee Share Ownership Participation Schemes (ESOPS).

- A new form of corporate governance is required that will create conditions for effective employee participation through a system of co-determination.

- The development of the small scale mining sector resulting from companies disposing of unwanted properties to black-owned companies or through the State, purposefully allocating its mineral rights to blackowned companies to address the inequity in the present distribution of mining industry ownership.

The South African Constitution provides within the Bill of Rights (South Africa 1996; ch.r 2, s. 24) that everyone has the right:

1. to an environment that is not harmful to his or her health or well-being and 
2. to have the environment protected for the benefit of present and future generations through reasonable legislative and other measures that

a. prevent pollution and ecological degradation

b. promote conservation and

c. secure ecologically sustainable development and use of natural resources, while promoting justifiable economic and social development, are provided.

The development needs of the people must be met while ensuring that the integrity of the environment remains unimpaired. To achieve the Government's goal of sustainable development, it is essential to integrate environmental impact management into all economic development activities (South Africa 1996). The central theme of the article of Kibreab (2001) is that mining projects entail a high degree of risk and have the potential to endanger the physical environment, among others. The requirement that equitable access to all natural resources be allowed may also incur an element of risk.

\section{The Bible weighs in on mining and the environment}

The Bible makes it plain that we are the stewards of the earth, and as such, our obligation is not negotiable. However, we are not obliged to preserve the natural world in some kind of frozen inertia at arm's length from human activity (Caldwell 2007). The church must be realistic and practical by its involvement in both preventative and interventional initiatives to heal the world of inhuman activities such as mining-induced displacement and settlement. A concerned theologian should carry out a reputable religious research on what the Bible says about mining. Applying one's mind to the issue, the researcher will discover that there is no biblical reference directed to mining as we see it today. However, there are a number of references within both the Old and the New Testament that highlight humans as being the stewards of the earth and its creatures, and charging them with using the earth's resources wisely.

The process of mining is described in Job 28:1-11. This text clearly indicates laborious search for valuable treasures out of the dark and deep earth. It has taken a considerable effort for humanity to develop ways to mine the earth for its precious metals such as silver, gold, iron, copper, and sapphires. The same effort is also exerted in agricultural activities (bread in v. 5). The threefold description of the remote location of the mine (away from where anyone lives, forgotten by travellers, and away from mankind) further indicates the difficulty and effort involved in humanity's pursuit of precious metals.

Mining practices in the ancient Near East have been neither fully discovered nor studied enough to determine precisely what is being pictured in this text, especially with reference to Job 28:4. It looks as if the people who gave rise to the Bible did almost no mining - they probably imported the mined products they needed from other countries. There are little or no traces of ancient mines being found in Palestine or Syria (Caldwell 2007).

A slightly more expansive view of mining in the Bible is provided by Genesis 2:10-12 [which] refers to the land of Havilah where there is gold and onyx stone. Both presumably had to be mined and were not 'created'. The Promised Land is, according to Deuteronomy 8:7-9, a land whose stones are iron and out of whose hills you can dig copper. Nothing [ $\mathrm{much}]$ very specific or exciting [is mentioned about that]. [Certainly there is] no guidance about the moral and ethical implications of mining. (Caldwell 2007)

It is disheartening to observe the absence of any specific biblical injunctions about mining. However, at least the topic can be approached afresh and unhindered by sectarian or philosophical constraints. There are numerous arguments relating to the Bible's teaching regarding environmental obligations or absence thereof, but we can leave those arguments to others for they are part of a much bigger debate in which mining is such a small part that for all practical purposes it is insignificant and irrelevant. There can be a move forward with clear conscience and rational mind to apply reason to the debate about where to mine and how to mine (Caldwell 2007).

\section{The mining impact on human environment}

The international debate on mining and its impact constantly refers to the problem of mining-induced displacement and resettlement (MIDR) that poses major risks to societal sustainability. The bottom line is that human activities such as MIDR affect ecosystems because they disturb the balance of the ecosystem. The sudden and extreme disturbance completely destroys the balance in the ecosystem, with the effect that the system cannot regain equilibrium by means of self-regulation and internal change. This leads to loss and destruction that is permanent. In general, the socioeconomic impact of mining needs to be assessed in the context of cultural erosion, weakened social structures, endemic poverty, and other social problems common to all affected communities in and around the mining areas. Mining activities disturb ecological harmony in diverse ways. The communities in close proximity of mining areas always run short of natural resources such as water (Miller 1992:484-485). The mining activities use a huge amount of water drilled from underground. This causes the water level underground to either subside to deeper levels or change the culture of flow (Grove 1994:197). This makes it difficult, if not impossible, for the communities to access underground water for human consumption or domestic utilisation.

The fertility of the top soil is always affected by the water drilled during the mining activities. This water is full of foreign elements such as alkaline or lime. These water components affect the top soil immensely, leading to poor crop production. The vegetation in the local mining areas gets affected and this leads to a wide imbalance in the ecosystem. The biodiversity changes and some creatures which used to balance the ecosystem get annihilated or forced into migration (Mobie \& Masango 2009:519-524). 
The environmental pollution is a menace to the communities and the vegetation in the close surrounds of the mining areas. Kibreab (2001) asserts rightly that

comparable examples of new poverty have been documented with the loss of access to public services, increased food insecurity, the loss of access to common property, social disarticulation, and the loss of civil and human rights. (pp. 9-10)

Many lives are lost due to inhaling the pollutants that are in the air due to extraction of poisonous particles from the earth. Tuberculosis has become the commonest outcome in making roads to those involved either as employees or those living closer to mining areas.

Mining activities also impact social coherence negatively. The economic covetousness of the mining magnates enhances the fact that the created universe is good, even though it has been corrupted by the selfish desires of creatures (Ward 1999:97). These magnates compensate in forms of royalties for the removals and the resettlements of the communities to give way for mining activities. This causes social disintegration by disturbing the cultural unity the community used to enjoy. The new settlement may be far from the servicing nodes such as schools, health facilities, places of employment, et cetera. One of the authorities in population resettlement issues, Michael M. Cernea (1995), in the essay, Understanding and preventing impoverishment from displacement: Reflections on the state of knowledge, brings this to attention:

Health risks associated with displacement are well documented. The already marginal health status of displaces is worsened by the stress and trauma of moving. Recurring problems are reported with resettled populations gaining access to safe potable water and safe sewage; increased diarrhoea, dysentery and epidemic infections often result. As might be expected, the health impacts fall disproportionately on infants, children, expecting mothers and the elderly. (p. 253)

The sentiment expressed by Cernea argues that in addition to health impacts on local populations as a result of contamination of air and water by the mining processes, numerous other impacts may result from mining development. These impacts include

increased rates of alcoholism and sexually-transmitted diseases as a result of migration of miners from outside the area; increased levels of family violence due to changes in the socio-economic structure of the community; and decreased access to country foods (e.g., wild meat) as a result of the ecological degradation; and an increase in conflicting human activities in traditional harvesting areas. These issues are addressed in great detail by the North-Slave Métis Alliance [2001] in their report Can't Live Without Work. (Hipwell et al. 2002:11).

In the recent past, the mining industry was notorious for family disintegration through the promotion of the migrant labour system. Christie (1996:43-45) refers to this system in South Africa as the contract labour system, or the labour bureaux and pass laws that operated to restrict the freedom of black workers. This was enhanced by a single sex living quarters system of housing. The exclusive hostel housing barred outsiders such as women or children from its precincts. Men of all ages leave their homes to be crowded in these quarters for the contracted period that they were working in the mines. Some social analysts discovered the emergence of a new and strange culture in these habitats, e.g. drugs, homosexuality, gangsterism, and others.

The other major communal disturbance caused by MIDR is the disruption of formal educational activities. Cernea (1995) notes that displacement and relocation often cause a significant interruption in the functioning of schools and in a child's access to education during the year of transfer or for longer periods of time. Empirical studies show that a number of these children never return to school and instead join the labour force at an early age. The chaos of relocation distracts parents from focusing on the concerns of their children as they struggle to reconstruct their physical and productive environment.

\section{Theological reflections}

There are two theological responses cited to address this socio-economic menace of MIDR. These are not exhaustive, but are proposals to positively make theology audible into the situation.

\section{Church as the leaven in the world}

With an enormous influence from Lumen gentium and Gaudium et spes, where the image of the church is a leaven in the world, it is here assumed that Matthew 13:33 speaks of the influence that the church (herein referred to as the kingdom of God) has. It also shows the role it can play in bringing order out of this chaos of economic greed that disturbs the balance and peace that the human-nature relationships enjoy. This notion is stressed by the definition that the church is the kingdom of God. The concept is supported by Paul S. Minear (1975) that:

There are places where a New Testament writer appears to identify the church and the Kingdom; and other places where distinctions are drawn between the two. But this need not produce confusion if, before one thinks 'church,' he has already thought 'the Kingdom of God,' or if one makes the ecclesiological term the predicate in a sentence the subject of which is the theological term. This suggestion may be further illustrated by the other idioms in which certain aspects of the Kingdom are applied to the being of the church. (pp. 124-125)

The kingdom of God defines the role of ekklesia because it is the latter's function to proclaim the kingdom. This idea is encapsulated by Engelbrecht and Van Dyk (1987) that

the kingdom of God is the goal of ekklesia ... The kingdom of God seems a much wider concept than ekklesia. While the ekklesia is militant by vocation (because it has to proclaim the kingdom in season and out of season as it were) it is the reality of the present age. (p. 107)

The role of ekklesia is therefore to proclaim the gospel of the kingdom. The ekklesia belongs to the present aeon and therefore has to challenge social injustices prevalent in the 
cosmos. Its presence in this age necessitates the proclamation of the truth; hence ekklesia will always be in conflict with everything opposed to the truth, because the truth is existentially in combat with evil.

The church as a leaven in a world is an image that expresses a vision of the world, with all its ambiguities and negativities, as an arena in which lives are lived out. The church as a leaven in the world gives the picture of social interactions intertwined with ecological questions regarding humancosmos relationships. The church is a social body with a commitment to social justice and to global relationality. This statement is often misunderstood, as it is also pointed out by Dennis M. Doyle (2000:16) that 'the Church that is as a leaven in the world of human events can also be construed as a leaven in the larger cosmos'. It is therefore hermeneutically correct to refer to the leaven of Matthew 13:33 as the power and the influence of ekklesia in cosmic events. These events are not just interventions, but curative in approach. The approaches must be the 'stronger emphasis in the paradigmatic shift from individual to community pastoral care ...' (Mouton 2014:93).

It is commonly known that leaven in the Hebrew worldview and language was a synonym for evil influence. Leaven can be viewed from two perspectives. In the New Testament $(\mathrm{Mt}$ 16:12; Mk 8:15), Jesus connotes leaven either as good or evil. Negatively, leaven can be viewed as the presence of evil. The apostle Paul (1 Cor 5:6; Gl 5:9) warns people against a little evil (leaven) that can spread corruption throughout the entire church. Luke equates leaven with hypocrisy or a poison to be avoided by the followers of Jesus Christ. Positively, like in the parable of Matthew 13:33, Jesus used the term leaven to describe the catalytic, all-permeating power of the kingdom of God, transforming the whole world as leaven transforms a lump of dough. Leaven symbolises the penetrating power of incarnational and proclamational dunamis of the gospel. The gospel goes beyond the human circumstantial borders. This is due to its dunamis. Speckman (2007:227) elaborates that 'dunamis has both material and political force behind it. Its corollary "empowerment" is the "active verb" describing the method of engendering power, length, etc.' Where it is latent or non-existent, for example in the case of a sick or disillusioned person, it is the 'how' of dunamis. William Barclay (1999:61) sees leaven as a symbol of the disturbing influence of Christianity. He (Barclay 1999) calls us to observe that

the working of the leaven in the dough is not a slow imperceptible process. At first it is true the leaven is hidden and nothing appears to happen; but soon the whole mass swells and bubbles as fermentation rapidly advances. (p. 61)

Without the leaven there is no 'good' bread. Without the leaven evil dominates the world. Without ekklesia the world is under condemnation. The church's proclamation of Jesus Christ restrains the evil in the cosmos. The world in its wealth search needs the addition of the influence of the ekklesia for human redemption. The question is, when there is evil rampant in the world, where is the leaven? Where is the penetrating power of the church?
The church is like leaven which has a tremendous influence on all that encounter it. As leaven is to the bread, the ekklesia provides purity in an otherwise evil world. The church as leaven in the world gradually brings light and righteousness into a darkened and chaotic world where humanenvironment equilibrium is disturbed by mining activities. The church as leaven is a force of social revolution. She has prophetic proclamation that continues to work pervasively, persistently, irreversibly, and invisibly until an entire mixture is made ready for the oven - for eschatological fulfilment. This fulfilment is realised when the church proactively intervenes to assist the victims of MIDR, whereby the victims' dignity is restored or compensated. The economic activities, though they interrupt harmonious social coherence, cannot reverse the process (influence) of the leaven - the church in the world.

\section{Ecclesiology should respond to the context of the mining industry}

Ecclesiology in context is when the church applies a combination of theological and social-scientific approaches to the development of practical models and strategies for the church's interaction with modern society and its challenges (Van der Ven 1996:5-21). For a very long time, as Torrence (1965:117-127) argues, ecclesiology in context had been stereotyped to practical theology, not systematic theology. This is an error that needs ratification with understanding that practical theology is the implementation of systematic theology, especially the branch known as ecclesiology.

Modern church practices cannot skirt around the realities faced by humanity in the face of MIDR, including all aspects based on socio-economic greed. The world is not merely an arena, as some people think, where humans just live out their lives and religious people carry out their mission. The world is where the Christian faith is called upon, or challenged to throw light (search, study, and harmonise) on everything that affects the human-nature relationship. Nature is not the enemy of humanity. The two are in a profound and mutual interrelationship. The genuine ecclesiality responds to the needs of human beings in relation to the environment they find themselves in. It is a genuine and authentic ecclesiality to draw the world into communion, reconciliation, and peace. The relationship between the church and the world repudiates any suggestion of humanity that is separated from, and privileged over, other people in the world. The Pastoral Constitution on the Church in the Modern World (Gaudium et Spes, par. 40, ch. 4) highlights the fact that it is true that the church,

at once a visible assembly and a spiritual communion, goes forward together with humanity and experiences the earthly lot of the world; she is like a leaven and a kind of soul for human society.

The authentic ecclesiology is not detached from the world. It is an intimate part of the world and humanity with human history is included.

I wish to concur with Van der Ven (1996) that the church in the world has four ecclesiastical functions. These functions 
are eclectic in approach and therefore not exhausted. I follow these functions with my own commentary.

\section{Identity}

This is a specific characteristic by which a church or a Christian is recognised or known. The mission of the church in the world, though not of the world, is to transform the world (Pelzel 2001:89-93). In the context of this article, identity has to deal with convictions, vision, and the mission of the church. The ecclesiastical community is called upon to maintain its prophetic role of valuing people above monetary profit. The mine magnates usually do the opposite. Ecclesiology is the relation of people to Christ and his church. These people do not relate in a vacuum. They are intertwined with a particular socio-cultural context that needs to be protected so that they can feel safe and secure. This includes even the environment in which they experience life. The church as a leaven in the world must find itself immersed into the issues facing the kingdom of God at large. Mildrow (quoted in Kritzinger, Meiring \& Saayman 1994:208) helps one to understand that for effective communication, identification is essential. This is not simply physical outward conformity, but a full and sympathetic entering into the life of others in an act meaningful in itself. One of the best ways of reclaiming our role as the church is through dialogue. Dialogue is a powerful tool that forges identification. This calls for self-denial, and it inevitably leads to the ability to serve.

Identification is the concept of being rather than doing. Our postmodern culture, largely influenced by the West, is the culture of doing - effectively and efficiently. This is how a person is judged or evaluated in a broader scope of society. Performance is a yard stick for effectiveness and success. By contrast, there is still a high degree of a 'being' culture which is still common in Africa and elsewhere. This is being together - a value that enhances the incarnational ministry of the church in a real sense. The church identity is one of being there. A leaven is soaked and absorbed by the dough and is invisible, though pervasive. The ekklesia is to be pervasive with invisible influence in the world. This does not call for covert activities, but for influence that is so irreversible and felt even by those who are in its opposition.

The church in the world is called upon to face the reality; accept the responsibility to sustain and heal the earth, and become a mature species. As members of the koinonia with Iesus Hominum Salvator (Jesus Saviour of humanity), ekklesia can no longer view the world in terms of 'we' and 'they' (Van der Ven 1996:78-79). Instead, there is only 'us' - a diverse, global community of interacting and interdependent individuals and species. Identification is being part of the world to become the salt and light of the world. It is our human duty primo pro patria (first place for our country) in regard to our interaction with nature.

The MIDR activities affect the church adversely, yet the church's prophetic stance must be known. As a result, the ekklesia must be convinced and convicted that there must be some theological response to the social and environmental disturbance. The ekklesia is theologically charged to identify with the victims of these activities. There must be a clear vision for the ekklesia in the context as to what the final product should look like after people had been affected. Then the mission must be clear as to how the vision will be expedited.

\section{Integration}

Integration is a process of combining into an integral whole. It is the action of incorporating a MIDR group into a community in which the church is an integral part. It has to deal with cohesion, uniformity, and pluriformity of the church. This is generally the focus on relationships among the affected communities. It is the dynamic interplay between the ekklesia and the community. There must be some element of spiritual fellowship or communion between human beings and God in contrast to juridical approaches that over-emphasise the institutional and legal aspects of the ekklesia. Integration reinforces communion ecclesiology which emphasises that the church is basically a 'communion' or fellowship among human beings and God (Doyle 2000:15). Integration focuses primarily on the relationship which is interconnectedness that lies at the heart of what ekklesia is. The cohesion of ekklesia in the midst of a MIDR era is the incarnation of love, forgiveness, acceptance, commitment, and intimacy. The church is a web of interwoven relationships. These relationships offer a share in the life of God as well as passage to a journey along with the ekklesia called to act as a leaven in the world. Just as a leaven is integrated into the dough, so should the church be integrated in order to influence the world.

\section{Policy}

Policy is a plan of action adopted by a church. It is in the line of the argument rationalising the course of action of a church, and it may include a written contract or certificate of insurance. It points to the development of church policy, programmes, and projects to be undertaken. The ekklesia must be intentional in addressing the imbalances left behind by the activities of the MIDR. The ecclesiology in context is the theology in praxis. The church must intentionally become proactive by designing policies that play advocacy for the victims of dispossession, violence, displacement, and marginalisation. Gabriel Mendy (2013:266) makes an appeal to the African church to 'readily take concrete steps to address the inhumane situations that generate division and violence in the society so that justice, peace, and unity will prevail'.

\section{Management}

Management shows the direction to be taken in areas of financial and human conditions balanced with the capacity of the church. This includes the administrative structure of the church, which is necessitated by the church's influence to and for the poor. The legacy that should be pursued by the church is the one of managing itself in a way that will 
benefit or bring some positive results for the betterment of the poor. These poor are the victims of the MIDR. The reality of the matter is that 'the cake is getting larger, and the slice which goes to the powerful and the rich is increasing, while the rest end up with much smaller portions' (Wahl 2009:626). Church management is one of the expressions of servant leadership by the ekklesia to the doomed world. This calls for stewardship into the chaotic world. Resources are to be managed in God-honouring manners, and this on its own is the gospel in demonstration. Ecclesiology in context embraces the fundamental truth expressed by Gunton (2002)

that which is created out of nothing remains essentially fragile and, given the fall, is always in danger of returning to the nothingness from which it came. It is part of the continuing care of God for the world that he protects it from its self-induced fate. (p. 28)

God can accomplish this through humanity which is placed in the cosmological context for the management of it at all cost. This is the task that can be achieved consilio et animis (by wisdom and courage). It is the human religious duty to ensure that the nature-human ecosystem balance is maintained and managed responsibly for the future generations (Badke 1991).

\section{Conclusion}

An appeal is made for the balance or a new relationship between the Christian and the world. Creation is to be perceived as an arena of resources, especially the minerals deposited inside the earth, for the survival of the generations to come. The mining industry is an old economic activity found even during ancient times of the Bible. The minerals are the resources that need some constitutional protection that calls for the policies that enable benefits to all those involved and affected by this economic activity. The church is called upon to address the after effects of the mininginduced displacement and resettlement (MIDR) activities. The church is rightly the fidei defensor (defender of the faith) and therefore must respond. The theological response should be ecclesiology in context, which calls for four major functions. These functions are identity, integration, policy and management. The ekklesia has the capacity to fulfil this mandate as a leaven in the world. Through partnership with God, the human being is capable of saving the earth, especially by promoting the four core functions mentioned at the end of this article. Lawler and Shanahan (1995) capture the spirit of this proposal correctly:

The perennial conflict between the world as created good by God and the world as corrupted by evil keeps in focus an important theological fact for the Church in communion, the fact that it is not by human effort alone, not simply by horizontal communion, that the world will reach fulfilment. Human effort alone goes only so far; fulfilment is, ultimately, a gift of God's Spirit, a gift of vertical communion. Still, the world possesses its own goodness, which for Christians is rooted in and clarified by the incarnation of God. To discover God's presence in the world, and to clarify this presence for those who do not have eyes to see it, is to discover and to clarify a radically new relationship between the gospel of God in Christ through the Spirit and human historical circumstance. (p. 139)

There is undoubtedly a great need to apply social-scientific theories in addressing the human needs in the context which the ecclesia finds itself. Flanagan (2013) concludes that hese theories must provide

a systematic way of understanding human society, and a framework by which an understanding of the actions of God in the world through the Son and Spirit could be connected with the concrete reality of the church. (p. 18)

\section{Acknowledgements Competing interests}

The author declares that he has no financial or personal relationships which may have inappropriately influenced him in writing this article.

\section{References}

Allen, R.B., 1984, The majesty of man: The dignity of being human, Multnomah Press, Portland, OR.

Badke, W.B., 1991, Project earth: Preserving the world God created, Multnomah Press, Portland, OR.

Barclay, W., 1999, The parables of Jesus, Westminster John Knox, Louisville, KY

Caldwell, J., 2007, 'Religion, mining, morality, and human behaviour', in InfoMine, viewed from http://www.infomine.com/publications/docs/ReligionandMining. pdf

Cernea, M.M., 1995, 'Understanding and preventing impoverishment from displacement: Reflections on the state of knowledge', Journal of Refugee Studies 8(3), 245-264. http://dx.doi.org/10.1093/jrs/8.3.245

Christie, P., 1996, The right to learn: The struggle for education in South Africa, Ravan Press, Randburg.

Doyle, D.M., 2000, Communion ecclesiology, Orbis Books, Maryknoll, NY.

Engelbrecht, J. \& Van Dyk, P.J., 1987, On creation and recreation: Themes from the Bible - Creation, justice, faith, and the church, Van Schaik, Pretoria.

Flanagan, B.P., 2013, Communion, diversity, and salvation: The contribution of JeanMarie Tillard to systematic ecclesiology, Clark, London.

Grove, A.T., 1994, The changing geography of Africa, 2nd edn., Oxford University Press, Oxford.

Gunton, C.E., 2002, The Christian faith: An introduction to Christian doctrine, Blackwell, Oxford.

Harris, F., 2005, Global environment issues, John Wiley, West Sussex.

Hipwell, W., Mamen, K., Weitzner, V and Whiteman, G., 2002, 'Aboriginal peoples and mining in Canada: Consultation, participation and prospects for change', Working discussion paper, prepared for The Norhth-South Institute.

Kibreab, G., 2001, 'Displacement, loss and constraints on (re)-construction of sustainable livelihoods', paper presented to the Workshop on moving targets - Displacement impoverishment and development, Cornell University, New York, NY.

Kritzinger, J.J., Meiring P.G.J. \& Saayman, W., 1994, On being witnesses, Orion Publishers, Halfway House.

Lawler, M.G. \&. Shanahan, T.J., 1995, Church: A spirited communion, The Liturgical Press, Collegeville, PA.

McGrath, A.E., 2000, Science and religion: An introduction, Blackwell, Oxford.

Mendy, G., 2013, Augustine's spirit-soul analogy: And its implications for communion ecclesiology, Publisher, Xlibris.

Miller, G.T. Jr, 1992, An introduction to environmental science: Living in the environment, 7th edn., Wadsworth Publishing, Belmont, TN.

Minear, P.S., 1975, Images of the church in the New Testament, The Westminster Press, Philadelphiam PA.

Mobie, T.R. \& Masango, M., 2009, 'Privatisation of water systems: Crime against humanity', HTS Teologiese Studies/Theological Studies 65(1), Art. \#325, 6 pages. http://dx.doi.org/10.4102/hts.v65i1.325

Moltmann, J., 1997, God in creation: An ecological doctrine of creation, SCM, London.

Mouton, D.P., 2014, 'Communities facing disruptions: The need to shift from individual to community paradigms in pastoral care', Acta Theologica 34(1), 17 pages. http:// dx.doi.org/10.4314/actat.v34i1.6

North-Slave Métis Alliance, 2001, 'Environmental, social, economic and cultural concerns: A companion to the comprehensive study report on the Diavik 
Diamonds Project: Can't live without work', viewed 24 November 2014, from http://www.reviewboard.ca/upload/project_document/EA0809004_NSMA Can_t_Live_Without_Work_-_2001.pdf

Pastoral Constitution on the Church in the Modern World, 1965, 'Gaudium et Spes, par. 40, Promulgated by his Holiness, Pope Paul VI on December 7, 1965' viewed 29 November 2014, from http://www.vatican.va/archive/hist_councils/ ii_vatican_council/documents/vat ii_cons_19651207_gaudium-et-spes_en.html

Pelzel, M., 2001, Ecclesiology: The church communion and mission, Loyola Press, Chicago, IL.

Peters, T., 2004, God-The world's future: Systematic theology for a new era, 2nd edn. Fortress, Minneapolis, MN.

South Africa, 1996, Constitution of the Republic of South Africa, Chapter 2: Bill of Rights, Government Printer, Pretoria.

South Africa, Department of Minerals \& Energy, 1998, White Paper: A minerals and mining policy for South Africa, October 1998, Department of Minerals and Energy, Pretoria.
Speckman, M.T., 2007, A biblical vision for Africa's development, Cluster Publications, Pietermaritzburg.

Stackhouse, M.L., Dearborn, T. \& Paeth, S., 2000, The local church in a global era, Eerdmans, Grand Rapids, MI.

Stott, J., 1990, Issues facing Christians today: New perspectives on social and moral dilemmas, Marshall Pickering, London.

Torrence, T.F., 1965, Theology in reconstruction, Eerdmans, Grand Rapids, MI.

Van der Ven, J., 1996, Ecclesiology in context, Eerdmans, Grand Rapids, MI.

Wahl, P., 2009, 'International financial markets and development', HTS Teologiese Studies/Theological Studies 65(1), Art. \#284, 4 pages. http://dx.doi.org/10.4102/ hts.v65i1.284

Ward, K., 1999, God, faith and the new millennium: Christian belief in an age of science, One Word, Oxford. 